\title{
Biogeographical distribution of the benthic thecate hydroids collected during the Spanish "Antártida 8611 " expedition and comparison between Antarctic and Magellan benthic hydroid faunas*
}

\author{
A. L. PEÑA CANTERO and A. M. GARCÍA CARRASCOSA \\ Departamento de Biología Animal, Facultad de Ciencias Biológicas, Dr. Moliner 50, \\ E-46100 Burjassot (Valencia), Spain.
}

\begin{abstract}
SUMMARY: The biogeographical distribution of the benthic hydroid species collected during the Spanish Antarctic expedition "Antártida 8611 " has been studied. An inventory of the Antarctic and Magellan benthic thecate hydroid faunas, along with a comparison between the two, have been also carried out. 104 and 126 species of thecate hydroids have been considered in the Antarctic and Magellan areas, respectively. 72 species (69\%) of the Antarctic species and 49 (39\%) of the Magellan species are endemic. 23 species are present both in the Antarctic Region and in the Magellan area, representing $22 \%$ and $18 \%$ respectively, and indicating an important relationship between both faunas.
\end{abstract}

Key words: Hydrozoa, biogeographic distribution, Antarctic region, Magellan region, Scotia Sea.

RESUMEN: DistrIBUCIÓN BIOGEOGRÁFICA DE LAS ESPECIES DE HIDROZOOS TECADOS BENTÓNICOS RECOGIDAS DURANTE LA CAMPAÑA “ANTÁRTIDA 8611" Y COMPARACIÓN ENTRE LA FAUNA DE HIDROZOOS BENTÓNICOS ANTÁRTICOS Y MAGALLÁNICOS. Se ha estudiado la distribución biogeográfica de las especies de hidrozoos bentónicos recogidos durante la campaña de prospección científico-pesquera "Antártida 8611". Asimismo, se ha realizado un inventario de la fauna de hidrozoos tecados bentónicos antárticos y magallánicos, habiéndose llevado a cabo una comparación entre ambas faunas. 104 y 126 especies de hidrozoos tecados se han considerado en las áreas antártica y magallánica respectivamente. 72 especies (69\%) de las especies antárticas y 49 (39\%) de las magallánicas son endémicas. 23 especies están presentes en ambas regiones, representando un $22 \%$ y un $18 \%$ respectivamente e indicando una importante relación entre ambas faunas.

Palabras clave: Hydrozoa, distribución biogeográfica, Antártida, región de Magallanes, Mar de Escocia.

\section{INTRODUCTION}

During the Spanish Antarctic expedition "Antártida 8611 " to the area of the Scotia Ridge islands, carried out in the austral summer of $1986-87$ by the Instituto Español de Oceanografía, a large amount of ben-

\footnotetext{
*Accepted October 22, 1998
}

thic samples were obtained by trawling. Hydroids was one of the zoological groups best represented in the studied area. Forty-six species were found, of which ten were identifed to generic level only, in many cases because of the scarce material available (cf. Peña Cantero and García Carrascosa, 1995).

In the present paper a study of the biogeographical distribution of the 36 species determined to spe- 
cific level has been undertaken. Furthermore, an inventory of both the Antarctic and Magellan benthic thecate hydroid fauna has been carried out. This aimed at estimating the relationship between the Antarctic hydroid fauna and that present in the Magellan region. Nevertheless, it is necessary to take into account the limitations concerning our knowledge of the hydroid fauna in those areas. Thus, for example, athecate hydroids, which were not present in the "Antártida 8611" collection, are poorly known both in the Antarctic region and in the Magellan area, and for this reason are not considered in the present study. Moreover, the hydroid fauna is still unknown in large areas of the Antarctic and not even the sampling efforts in the area so far studied have been uniform.

\section{MATERIAL AND METHODS}

Figure 1 represents the itinerary followed during the "Antártida 8611" expedition. In Figure 2 are represented the different areas studied, along with the stations in which hydroid species were obtained.

In defining the limits of the Antarctic region the ideas stated by Hedgpeth (1969), and basically followed by Picken (1985) and Knox (1995), are considered. According to those authors the Antarctic region covers the whole of the area south of the Antarctic Convergence, whereas the Sub-Antarctic region includes the area between the Antarctic Convergence and the Sub-tropical Convergence. In this study, however, Andriashev (1964) and Picken (1985) have been followed in considering the northern limit of the pack-ice as the most valid limit for the Antarctic benthos. To the Magellan area the limits stated by Briggs (1974) have been followed; this author situated the northern Atlantic limit at the mouth of the Río de la Plata (Argentina) and the northern Pacific limit at the northern tip of Chiloé Island (Chile).

In this paper, Circum-Antarctic distribution indicates the distribution throughout the Antarctic region; Pan-Antarctic distribution also includes the distribution throughout the Sub-Antarctic region. Antarctic-Kerguelen and Antarctic-Patagonian distributions refer to the distribution throughout the Antarctic and either the Sub-Antarctic islands or the Magellan area, respectively.

Due to the absence of athecate hydroids in the "Antártida 8611" collection, and the scarce knowledge of this group both in the Antarctic region and the Magellan area, they are not included in this study.

The distribution of the hydroid species considered in this study has been reconstructed using infor-

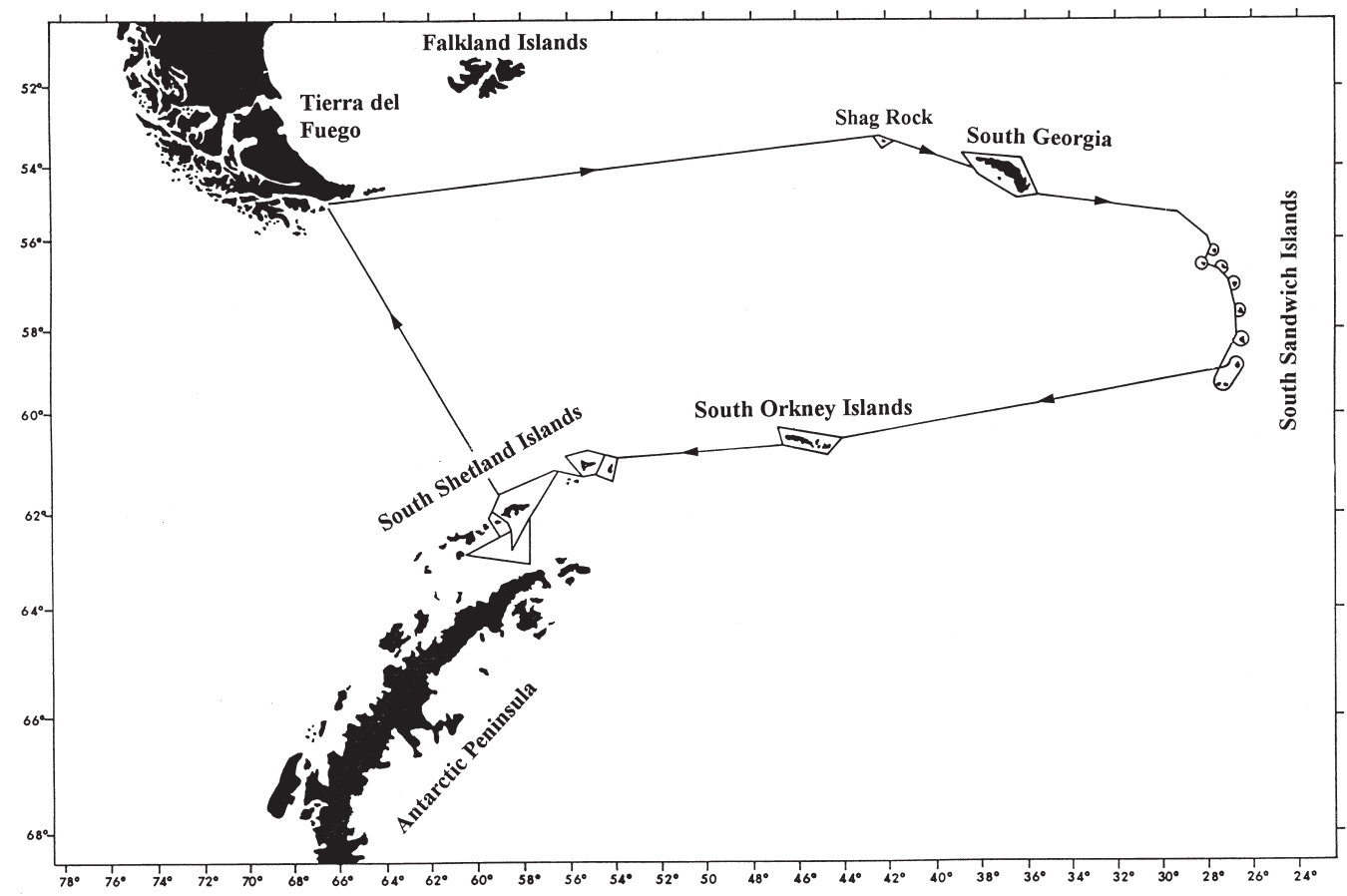

FIG. 1. - Itinerary followed during the Spanish Antarctic expedition "Antártida 8611". 

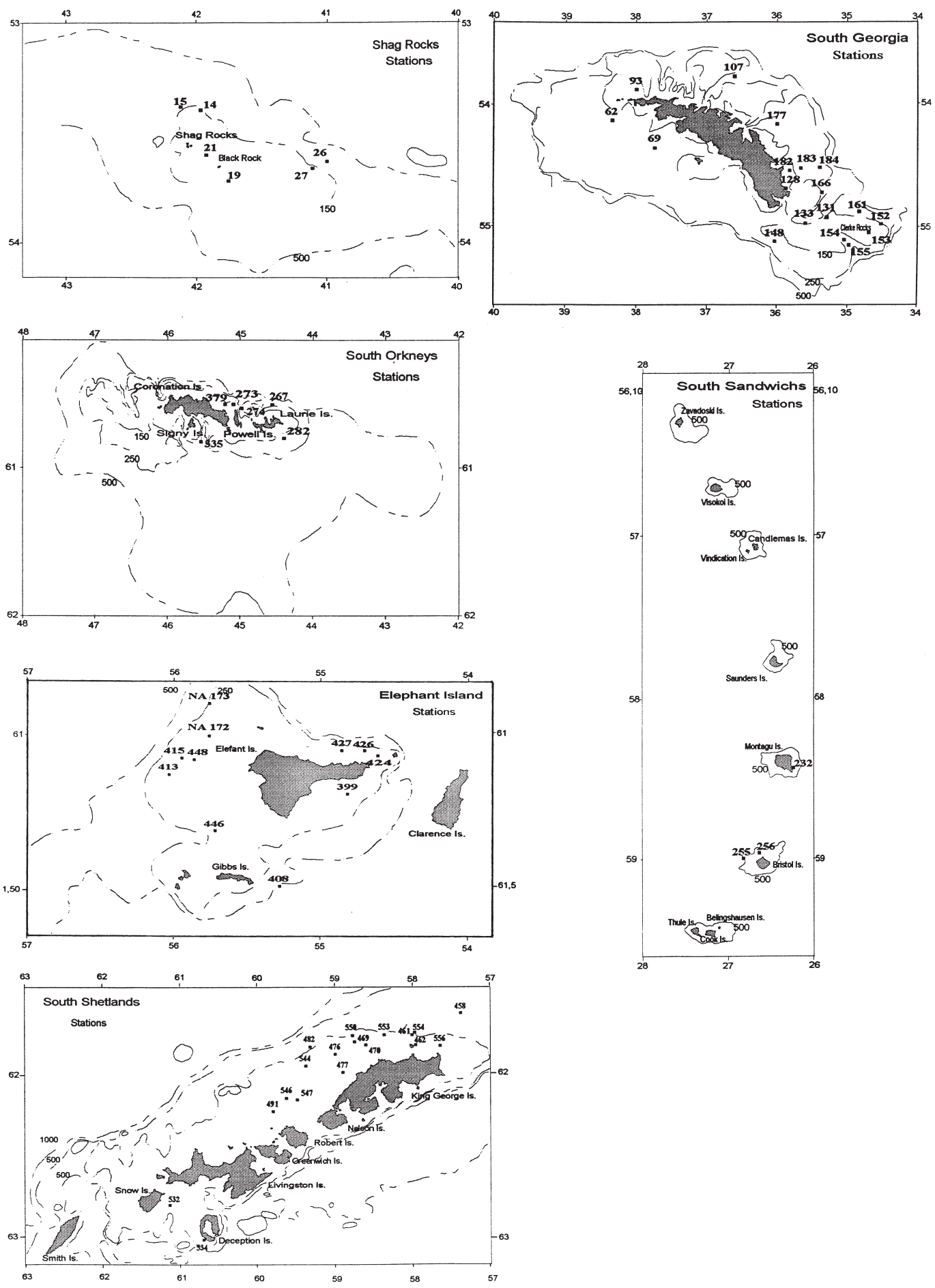

FIG. 2. - Areas studied during the Spanish Antarctic expedition "Antártida 8611", showing the stations in which species of hydroids were found (see also Table 1).

mation obtained from Blanco (1994), El Beshbeeshy (1991), Hartlaub (1905), Peña Cantero (1998), Peña Cantero and García Carrascosa $(1995,1998)$, Peña Cantero et al. (1997), Peña Cantero and Vervoort (1998), Peña Cantero et al. (1997a, 1997b) and Stepan'yants (1979).

\section{RESULTS AND DISCUSSION}

In Table 1 is shown the list of the 36 species collected during the "Antártida 8611" expedition and determined to specific level. The most important feature is the high degree of endemism at the specif- 
TABLE 1. - Species of benthic hydroids collected during the "Antártida 8611" expedition. (Distribution: AK, Antarctic-Kerguelen; AP, Antarctic-Patagonian; CA, Circum-Antarctic; MA, Multiaustral; PA, Pan-Antarctic; SA, Sub-Antarctic; W, Worldwide; WA, West Antarctic).

\begin{tabular}{|c|c|c|c|}
\hline Species & Stations & Depth (m) & Distribution \\
\hline \multicolumn{4}{|l|}{ Lafoeidae Hincks, 1868} \\
\hline \multicolumn{4}{|l|}{ Abietinella Levinsen, 1813} \\
\hline A. operculata (Jäderholm, 1903) & $133,408,470,491,550,556$, NA 173 & $63-471$ & AP \\
\hline & & & \\
\hline $\begin{array}{l}\text { H. striata Allman, } 1888 \\
\text { Lafoea Lamouroux, } 1821\end{array}$ & 491, NA 173 & 63 & PA \\
\hline L. dumosa (Fleming, 1820) & $14,19,128,133,184,470$ & $150-246$ & W \\
\hline \multicolumn{4}{|l|}{ Haleciidae Hincks, 1868} \\
\hline \multicolumn{4}{|l|}{ Halecium Oken, 1815} \\
\hline H. delicatulum (Coughtrey, 1876) & $21,470,556$ & $140-202$ & W \\
\hline H. ovatum Totton, 1930 & 408 & $438-471$ & CA \\
\hline \multicolumn{4}{|l|}{ Hydrodendron Hincks, 1874} \\
\hline \multirow{2}{*}{\multicolumn{4}{|c|}{ Halopterididae Millard, 1962}} \\
\hline & & & \\
\hline \multicolumn{4}{|l|}{ Schizotricha Allman, 1883} \\
\hline S. anderssoni Jäderholm, 1904 & $93,133,152,161,183$ & $91-254$ & $\mathrm{CA}$ \\
\hline S. falcata Peña Cantero, 1998 & 470 & $150-154$ & WA \\
\hline S. multifurcata Allman, 1883 & $232,255,256$ & $100-194$ & SA \\
\hline S. turqueti Billard, 1906 & 413,446 & $164-261$ & WA \\
\hline S. vervoorti Peña Cantero, 1998 & 379,462 & $51-149$ & WA \\
\hline \multicolumn{4}{|l|}{ Kirchenpaueriidae Millard, 1962} \\
\hline \multicolumn{4}{|l|}{ Oswaldella Stechow, 1919} \\
\hline O. elongata Peña Cantero, García Carrascosa and Vervoort, 1995 & 161,182 & $86-250$ & WA \\
\hline O. grandis Peña Cantero, Svoboda and Vervoort, 1997 & NA 172 & $?$ & WA \\
\hline O. incognita Peña Cantero, Svoboda and Vervoort, 1997 & 446 & 234-261 & WA \\
\hline O. shetlandica Stepan'yants, 1979 & $470,476,553$ & $150-216$ & WA \\
\hline \multicolumn{4}{|l|}{ Sertulariidae Hincks, 1868} \\
\hline \multicolumn{4}{|l|}{ Antarctoscyphus Peña Cantero, García Carrascosa and Vervoort, 1997} \\
\hline A. asymmetricus Peña Cantero, García Carrascosa and Vervoort, 1997 & $133,256,446,476, \mathrm{NA} 173$ & $100-261$ & WA \\
\hline A. elongatus (Jäderholm, 1904) & NA172 & ? & $\mathrm{AK}$ \\
\hline A. encarnae Peña Cantero, García Carrascosa and Vervoort, 1997 & 469,477 & $100-220$ & WA \\
\hline A. spiralis (Hickson and Gravely, 1907) & $256,274,491$ & $63-369$ & $\mathrm{CA}$ \\
\hline \multicolumn{4}{|l|}{ Staurotheca Allman, 1888} \\
\hline S. affinis (Jäderholm, 1904) & 128 & 198-202 & WA \\
\hline S. compressa Briggs, 1938 & $\begin{array}{l}399,408,413,415,426,446,462,469, \\
470,476,477,482,532\end{array}$ & $51-475$ & $\mathrm{CA}$ \\
\hline S. dichotoma Allman, 1888 & $15,131,161,184,491,534,544,546$, NA173 & $7363-250$ & AK \\
\hline S. frigida Peña Cantero, Svoboda and Vervoort, 1997 & $133,148,153,155,161,177,182,183,282$ & $86-330$ & AK \\
\hline S. juncea (Vanhöffen, 1910) & $427,446,448,469$ & $117-261$ & CA \\
\hline S. pachyclada (Jäderholm, 1904) & $\begin{array}{l}14,19,26,27,62,69,107,131,415,424 \\
448,461,546,554\end{array}$ & , $74-400$ & WA \\
\hline S. vanhoeffeni (Peña Cantero and García Carrascosa, 1993) & $424,461,476$ & $196-400$ & $\mathrm{CA}$ \\
\hline Staurotheca sp. nov. 1 & 155 & $279-330$ & WA \\
\hline Staurotheca sp. nov. 2 & $128,133,154,183,184,255,256$ & $100-254$ & WA \\
\hline Staurotheca sp. nov. 3 & 446 & $234-261$ & WA \\
\hline Staurotheca sp. nov. 4 & 476 & $198-215$ & WA \\
\hline Staurotheca sp. nov. 5 & $273,446,458$ & 234-407 & WA \\
\hline \multicolumn{4}{|l|}{ Symplectoscyphus Marktanner-Turneretscher, 1890} \\
\hline S. curvatus (Jäderholm, 1917) & 461,470 & $150-232$ & CA \\
\hline S. glacialis (Jäderholm, 1904) & $155,273,413,424,426,446,477,554,556$ & $111-475$ & $\mathrm{AK}$ \\
\hline S. subdichotomous (Kirchenpauer, 1884) & 133 & $229-240$ & MA \\
\hline S. vanhoeffeni Totton, 1930 & 267 & $166-208$ & $\mathrm{CA}$ \\
\hline \multirow{2}{*}{\multicolumn{4}{|c|}{ Campanulariidae Hincks, 1868}} \\
\hline Billardia Totton, 1930 & & & \\
\hline B. subrufa (Jäderholm, 1904) & $273,469,554,556$ & $111-267$ & AP \\
\hline
\end{tabular}

ic level. As shown in Table 1, of 36 species determined to the specific level, $24(67 \%)$ are endemic in the Antarctic region. Furthermore, sixteen of these species (44\%) are endemic in West Antarctica, being restricted in their distribution to the area of the Antarctic Peninsula, Bellingshausen Sea, Weddell Sea and the Scotia Sea islands (S. affinis, Staurotheca sp. nov. 1 and $O$. elongata have only been record- ed at South Georgia which is usually considered as a district in the Antarctic region).

Eight species may be considered to have a Circum-Antarctic distribution (i.e. present both in East and West Antarctica).

There are eight species distributed both in Antarctic and Sub-Antarctic waters. Of those, only $H$. striata and H. arboreum may be considered Pan- 
Antarctic species, being present both in the Magellan and in the Kerguelen areas. At present, four species (A. elongatus, S. dichotoma, S. frigida and $S$. glacialis) are considered to have an Antarctic-Kerguelen distribution, their records are restricted to the Antarctic and Kerguelen areas (there are no records of these species in the Magellan area). Alternatively, two species (A. operculata and B. subrufa) might be considered to be Antarctic-Patagonian species, since their records are restricted to the Antarctic and the Magellan areas (they have never been recorded in the Kerguelen area).

Symplectoscyphus subdichotomous has usually been recorded in Sub-Antarctic waters, though in a few occasions in Antarctic waters as well. Schizotricha multifurcata might be considered a Sub-Antarctic species, being present in the Magellan and in the Kerguelen areas with the most southern record at the South Sandwich islands. The remaining two species, $H$. delicatulum and $L$. dumosa, have an almost cosmopolitan distribution.

These results are similar to those obtained if all the known Antarctic thecate hydroid species are considered (Table 2). Thus, at specific level, the originality of the Antarctic benthic thecate hydroid fauna is remarkable, since $72(69 \%)$ of the 104 species determined to specific level are endemic in the Antarctic region. Stepan'yants (1979), in a study on the Antarctic and Sub-Antarctic species of hydroids, found that of 91 species present in the Antarctic region, 44 species (48\%) were endemic in that region.

The degree of endemism in the Antarctic benthic hydroid fauna is similar to that found in other invertebrate groups; e.g. $81 \%$ of endemic species in Cheilostomatous Bryozoa (Hayward, 1995), $77 \%$ in Echinoidea (Pawson, 1969) or 57\% in Polychaeta (Knox and Lowry, 1977). Nevertheless, it is lower than in other groups; e.g. $>90 \%$ in Pycnogonida (Fry, 1964), 95\% in Amphipoda (Jazdzewski et al., 1991) or $87 \%$ in Isopoda (Brandt, 1991).

At present, as is shown in Table 2, of the 72 endemic species, 21 (29\%) may be considered to have a Circum-Antarctic distribution. The remaining endemic species are either endemic in East Antarctica (5 species or $7 \%$ ) or in West Antarctica (46 species or $64 \%$ ). These results contrast with those obtained by Stepan'yants (1979) who found that of 44 endemic species in the Antarctic region (see above), 13 (14\%) were endemic in East Antarctica and $11(12 \%)$ in West Antarctica. The much higher number of endemic species in West Antarcti- ca, at present, may be due to the unequal sampling and study efforts in East and West Antarctica since Stepan'yants paper.

The originality of the Antarctic hydroid fauna is greater if we consider the Antarctic species also present in Sub-Antarctic waters. Here are included the five species with Pan-Antarctic distribution, the two species with Sub-Antarctic distribution, the five species with Antarctic-Patagonian distribution and the nine species with an Antarctic-Kerguelen distribution. Thus, the number of Antarctic species either endemic in the Antarctic region or in Antarctic and Sub-Antarctic waters is raised to 93, representing $c a$ $89 \%$ of the 104 species of thecate hydroids determined to specific level.

Only 11 Antarctic species of benthic thecate hydroids are also present outside the area comprised by Antarctic and Sub-Antarctic waters. These are four species with a multiaustral distribution, two bipolar species, one circumglobal species and four species with a worldwide distribution.

None of the 23 genera with representatives in the Antarctic region is endemic in this area. However, the genera Stegella, Staurotheca, Antarctoscyphus and Oswaldella are probably genera with the Antarctic region as centre of origin. Thus, of 23 species referred to Staurotheca [ $c f$. Peña Cantero et al. (1997a) and present paper], 19 species are endemic in the Antarctic region, two have an Antarctic-Kerguelen distribution and the remaining two are endemic in the Magellan area. Of 22 species referred to Oswaldella ( $c f$. Peña Cantero and Vervoort, 1998 and Peña Cantero and García Carrascosa, 1998) 21 are endemic in the Antarctic region, the majority being restricted to the continental Antarctic region (high Antarctica and Scotia Ridge), the remaining one is endemic in the Magellan region. Of eight known species of Antarctoscyphus [cf. Peña Cantero et al. (1997)], seven are endemic in the Antarctic region, whereas the remaining has an Antarctic-Kerguelen distribution. Finally, the single member of the genus Stegella (S. grandis) has an Antarctic-Kerguelen distribution.

In the Antarctic region there are also other invertebrate groups without endemic genera (e.g. Porifera or Bryozoa), whereas other groups have either a low endemism [e.g. 5\% in Holothuroidea and Polychaeta, cf. Pawson (1969) and Knox and Lowry (1977), respectively] or a relatively high endemism [e.g. 25\% in Echinoidea (Pawson, 1969), 39\% in Amphipoda (Knox and Lowry, 1977)]. 
TABLE 2. - Families, genera and species of thecate hydroids reported both in the Antarctic Region and in the Magellan area (common species in bold). (Distribution: AA, Amphi-Atlantic; AK, Antarctic-Kerguelen; AP, Antarctic-Patagonian; BP, Bipolar; CA, Circum-Antarctic; CG, CircumGlobal; CT, Circum-Tropical; D, Disjunct; EA, East Antarctic; KP, Kerguelen-Patagonian; M, Magellan; MA, Multiaustral; PA, Pan-Antarctic; S, Scattered; SA, Sub-Antarctic; T/ST, Tropical/Sub-tropical; W, Worldwide; WA, West Antarctic; WT, Widespread in temperate waters).

\begin{tabular}{|c|c|c|c|}
\hline $\begin{array}{l}\text { Magellan area } \\
\text { Species }\end{array}$ & Distribution & $\begin{array}{l}\text { Antarctic region } \\
\text { Species }\end{array}$ & Distribution \\
\hline \multicolumn{2}{|l|}{ Campanulinidae Hincks, 1868} & \multicolumn{2}{|l|}{ Campanulinidae Hincks, 1868} \\
\hline $\begin{array}{l}\text { Opercularella Hincks, } 1868 \\
\text { O. belgicae (Hartlaub, 1904) }\end{array}$ & PA & $\begin{array}{l}\text { Lafoelna G. U. Sars, } 1874 \\
\text { L. longitheca Jäderholm, } 1904\end{array}$ & $\mathrm{AK}$ \\
\hline $\begin{array}{l}\text { Phialellidae Russell, } 1953 \\
\text { Phialella Browne } 1902\end{array}$ & & Opercularella Hincks, 1868 & \\
\hline $\begin{array}{l}\text { Phialella Browne, } 1902 \\
\text { P. chilensis (Hartlaub, 1905) }\end{array}$ & PA & $\begin{array}{l}\text { O. belgicae (Hartlaub, 1904) } \\
\text { Stegella Stechow, } 1919\end{array}$ & PA \\
\hline \multirow{2}{*}{\multicolumn{2}{|c|}{$\begin{array}{l}\text { Tiarannidae Russell, } 1940 \\
\text { Modeeria Forbes, } 1848\end{array}$}} & S. grandis (Hickson and Gravely, 1907) & $\mathrm{AK}$ \\
\hline & & Phialellidae Russell, 1953 & \\
\hline $\begin{array}{l}\text { M. rotunda (Quay and Gaimard, 1827) } \\
\text { Stegoopama Levinsen } 1893\end{array}$ & W & Phialella Browne, 1902 & \\
\hline $\begin{array}{l}\text { Stegopoma Levinsen, } 1893 \\
\text { S. fastigiatum (Alder, 1860) }\end{array}$ & WT & $\begin{array}{c}\boldsymbol{P} \text {. chilensis (Hartlaub, 1905) } \\
\text { Tiarannidae Russell } 1940\end{array}$ & PA \\
\hline S. irregularis Totton, 1930 & MA & $\begin{array}{l}\text { TIarannidae Russell, } 1940 \\
\text { Stegopoma Levinsen, } 1893\end{array}$ & \\
\hline & $\mathrm{BP}$ & S. irregularis Totton, 1930 & MA \\
\hline \multicolumn{2}{|l|}{$\begin{array}{l}\text { Lafoeidae Hincks, } 1868 \\
\text { Abietinella Levinsen } 1913\end{array}$} & $\begin{array}{l}\text { S. plicatile (M. Sars, 1863) } \\
\text { Lafoeidae Hincks, } 1868\end{array}$ & BP \\
\hline $\begin{array}{l}\text { A. operculata (Jäderholm, 1903) } \\
\text { A crvptolaria Norman } 1875\end{array}$ & AP & Abietinella Levinsen, 1913 & \\
\hline $\begin{array}{l}\text { Acryptolaria Norman, } 1875 \\
\text { A conferta (Allman } 1877 \text { ) }\end{array}$ & W & A. operculata (Jäderholm, 1903) & AP \\
\hline $\begin{array}{l}\text { A. conferta (Allman, 1877) } \\
\text { A. crassicaulis (Allman, 1888) }\end{array}$ & W & $\begin{array}{l}\text { Acryptolaria Norman, } 1875 \\
\text { A corniformis Naumoy and Stepan'vants, } 1962\end{array}$ & \\
\hline A. operculata Stepan'yants, 1979 & $\mathrm{M}$ & $\begin{array}{l}\text { A. corniformis Naumov and Stepan yants, } 1962 \\
\text { Filellum Hincks, } 1868\end{array}$ & EA \\
\hline \multicolumn{2}{|l|}{$\begin{array}{l}\text { A patagonica } \mathrm{El} \text { Beshbeeshy, } 1991 \\
\text { Filellum Hincks, } 1868\end{array}$} & F. antarcticum (Hartlaub, 1904) & MA \\
\hline F. antarcticum (Hartlaub, 1904) & MA & $\begin{array}{l}\text { F. serpens (Hassall, 1848) } \\
\text { Halisiphonia Allman, 1888 }\end{array}$ & W \\
\hline $\begin{array}{l}\text { F. serpens (Hassall, 1848) } \\
\text { F. serratum (Clarke, 1879) }\end{array}$ & $\mathrm{W}$ & H. nana Stechow, 1921 & WA \\
\hline $\begin{array}{l}\text { F. serratum (Clarke, 1879) } \\
\text { Grammaria Stimpson, 1854 }\end{array}$ & WT & $\begin{array}{l}\text { Hebella Allman, } 1888 \\
\text { H. plana Ritchie, } 1907\end{array}$ & $\mathrm{AP}$ \\
\hline $\begin{array}{l}\text { G. abietina (M. Sars, 1850) } \\
\text { Hehella Allman } 1888\end{array}$ & $\mathrm{D}$ & H. striata Allman, 1888 & $\begin{array}{l}\text { AP } \\
\text { PA }\end{array}$ \\
\hline $\begin{array}{l}\text { Hebella Allman, } 1888 \\
\text { H. calcarata (Agassiz, 1862) }\end{array}$ & W & $\begin{array}{l}\text { Lafoea Lamouroux, } 1821 \\
\text { L. dumosa (Fleming, 1820) }\end{array}$ & \\
\hline H. plana Ritchie, 1907 & AP & $\begin{array}{l}\text { L. dumosa (Fleming, } 1820) \\
\text { L. gaussica Vanhöffen, } 1910\end{array}$ & EA \\
\hline $\begin{array}{l}\text { H. striata Allman, } 1888 \\
\text { Lfoe }\end{array}$ & PA & $\begin{array}{l}\text { Haleciidae Hincks, } 1868 \\
\text { Halecium Oken } 1815\end{array}$ & \\
\hline $\begin{array}{l}\text { La dumosa (Fleming, 1820) } \\
\text { L. dum }\end{array}$ & $\mathrm{W}$ & $\begin{array}{l}\text { Halecium Oken, } 1815 \\
\text { H. delicatulum Coughtrey, } 1876\end{array}$ & W \\
\hline \multicolumn{2}{|l|}{$\begin{array}{l}\text { Haleciidae Hincks, } 1868 \\
\text { Halecium Oken, } 1815\end{array}$} & H. incertus Naumov and Stepan'yants, 1962 & $\mathrm{AK}$ \\
\hline $\begin{array}{l}\text { Halecium Oken, } 1815 \\
\quad \text { H. beanii (Johnston, 1838) }\end{array}$ & W & H. interpolatum Ritchie, 1907 & WA \\
\hline H. cymifore Allman, 1888 & M & $\begin{array}{l}\text { H. jaederholmi Vervoort, } 1972 \\
\text { H. ovatum Totton, } 1930\end{array}$ & PA \\
\hline H. delicatulum Coughtrey, 1876 & $\mathrm{~W}$ & H. pallens Jäderholm, 1904 & $\mathrm{CA}$ \\
\hline H. fraseri Ralph, 1958 & $\mathrm{D}$ & H. secundum Jäderholm, 1904 & WA \\
\hline H. jaederholmi Vervoort, 1972 & PA & H. tenellum Hincks, 1861 & $\mathrm{~W}$ \\
\hline $\begin{array}{l}\text { H. tenellum Hincks, } 1861 \\
\text { Hydrodendron Hincks, } 1874\end{array}$ & W & $\begin{array}{l}\text { Hydrodendron Hincks, } 1874 \\
\text { H arboreum (Allman. 1888) }\end{array}$ & PA \\
\hline H. arboreum (Allman, 1888) & PA & Halopterididae Millard, 1962 , 1000) & $\mathrm{FA}$ \\
\hline \multirow{2}{*}{\multicolumn{2}{|c|}{$\begin{array}{c}\text { Aglaopheniidae Broch, } 1918 \\
\text { Aglaophenia Lamouroux, } 1812\end{array}$}} & Schizotricha Allman, 1883 & \\
\hline & & S. anderssoni Jäderholm, 1905 & CA \\
\hline A. acacia Allman, 1883 & AA & S. falcata Peña Cantero, 1998 & WA \\
\hline A. antarctica Jäderholm, 1903 & $\mathrm{M}$ & S. glacialis (Hickson and Gravely, 1907) & $\mathrm{CA}$ \\
\hline Cladocarpus Allman, 1874 & & S. jaederholmi Peña Cantero and Vervoort, 1996 & WA \\
\hline C. cornutus Verrill, 1879 & $\mathrm{D}$ & S. multifurcata Allman, 1883 & SA \\
\hline Lytocarpia Stechow, 1919 & & S. nana Peña Cantero et al., 1996 & $\mathrm{CA}$ \\
\hline L. canepa Blanco and De Miralles, 1971 & M & S. turqueti Billard, 1906 & WA \\
\hline $\begin{array}{l}\text { L. distans Allman, } 1877 \\
\text { L. vervoorti Stepan'vants, } 1979\end{array}$ & AA & S. unifurcata Allman, 1883 & $\mathrm{AK}$ \\
\hline \multirow{2}{*}{\multicolumn{2}{|c|}{$\begin{array}{c}\text { Halopterididae Millard, } 1962 \\
\text { Halopteris Allman, } 1877\end{array}$}} & $\begin{array}{l}\text { S. vervoorti Peña Cantero, } 1998 \\
\text { hennaueriidae Millard } 1962\end{array}$ & WA \\
\hline & & $\begin{array}{l}\text { rchenpaueriidae Millard, } 1962 \\
\text { Oswaldella Stechow, } 1919\end{array}$ & \\
\hline H. catharina (Johnston, 1833) & AA & O. antarctica (Jäderholm, 1904) & WA \\
\hline H. constricta Totton, 1930 & SA & O. bifurca (Hartlaub, 1904) & WA \\
\hline H. diaphana (Heller, 1868) & $\mathrm{CT}$ & O. billardi Briggs, 1938 & EA \\
\hline Schizotricha Allman, 1883 & & O. blanconae EP Beshbeeshy, 1991 & WA \\
\hline S. multifurcata Allman, 1883 & SA & O. crassa Peña Cantero and Vervoort, 1998 & WA \\
\hline \multicolumn{2}{|l|}{$\begin{array}{c}\text { Kirchenpaueriidae Millard, } 1962 \\
\text { Oswaldella Stechow, } 1919\end{array}$} & O. curiosa Peña Cantero and Vervoort, 1998 & WA \\
\hline Oswaldella Stechow, 1919 & & O. delicata Peña Cantero et al., 1997 & WA \\
\hline O. herwigi $\mathrm{El}$ Beshbeeshy, 1991 & M & O. elongata Peña Cantero et al., 1995 & WA \\
\hline \multicolumn{2}{|l|}{$\begin{array}{l}\text { Plumulariidae Hincks, } 1868, \\
\text { Nemertesia Lamouroux, } 1812\end{array}$} & O. encarnae Peña Cantero et al., 1997 & WA \\
\hline Nemertesia Lamouroux, 1812 & & O. erratum Peña Cantero and Vervoort, 1997 & WA \\
\hline N. cymodocea (Busk, 1851) & SA & O. garciacarrascosai Peña Cantero et al., 1997 & WA \\
\hline \multirow{2}{*}{\multicolumn{2}{|c|}{$\begin{array}{l}\text { N. vervoorti El Beshbees } \\
\text { Plumularia Lamarck, } 1815\end{array}$}} & O. gracilis Peña Cantero et al., 1997 & WA \\
\hline & & O. grandis Peña Cantero et al., 1997 & WA \\
\hline P. diploptera Totton, 1930 & SA & O. incognita Peña Cantero et al., 1997 & WA \\
\hline P. duseni Jäderholm, 1904 & M & O. obscura Peña Cantero et al., 1997 & WA \\
\hline P. curvata Jäderholm, 1904 & $\mathrm{M}$ & O. rigida Peña Cantero et al., 1997 & $\mathrm{CA}$ \\
\hline P. leloupi Blanco and De Miralles, 1971 & $\mathrm{M}$ & O. shetlandica Stepan'yants, 1979 & WA \\
\hline P. pulchella Bale, 1882 & SA & O. stepanjantsae El Beshbeeshy, 1991 & $\mathrm{CA}$ \\
\hline P. setacea (Linnaeus, 1758) & $\mathrm{CG}$ & O. terranovae Peña Cantero and Vervoort, 1996 & EA \\
\hline P. vervoorti El Beshbeeshy, 1991 & $\mathrm{M}$ & O. tottoni Peña Cantero and Vervoort, 1996 & $\mathrm{CA}$ \\
\hline Sertulariidae Hincks, 1868 & & O. vervoorti Peña Cantero and García Carrascosa (1998) & WA \\
\hline Abietinaria Kirchenpauer, 1884 & & Sertulariidae Hincks, 1868 & \\
\hline A. abietina (Linnaeus, 1758) & $S$ & Antarctoscyphus Peña Cantero et al., 1997 & \\
\hline $\begin{array}{l}\text { Sassiz, } 1862 \\
\text { (Gray, 1843) }\end{array}$ & & A. asymmetricus Peña Cantero et al. 1997 & WA \\
\hline $\begin{array}{l}\text { A. bispinosa (Gray, 1843) } \\
\text { A. episcopus (Allman, } 1876 \text { ) }\end{array}$ & SA & A. biformis (Jäderholm, 1905) & $\begin{array}{l}\text { WA } \\
\text { AK }\end{array}$ \\
\hline $\begin{array}{l}\text { A. episcopus (Allman, } 1876) \\
\text { A. minima (Thompson, 1879) }\end{array}$ & SA & $\begin{array}{l}\text { A. elongatus (Jäderholm, 1904) } \\
\text { A. encarnae Peña Cantero et al., } 1997\end{array}$ & WA \\
\hline A. norte El Beshbeeshy, 1991 & M & A. grandis (Blanco, 1977) & $\mathrm{CA}$ \\
\hline A. operculata (Linnaeus, 1758) & $\mathrm{W}$ & A. gruzovi (Stepan'yants, 1979) & WA \\
\hline
\end{tabular}


A. trispinosa (Coughtrey, 1875)

Dynamena Lam

D. pumilla (Linnaeus, 1758)

Parascyphus Ritchie, 191

$P$. repens (Jäderholm, 1904)

Parathuiaria Leloup, 1974

P. polycarpa (Kirchenpauer, 1884)

Sertularella Gray, 1847

S. allmani Hartlaub, 1900

$S$ antarctica Hartlaub 1900

S. argentinica El Beshbeeshy, 1991

S. blanconae El Beshbeeshy, 1991

$S$. contorta Kirchenpauer, 1884

S. cruzensis El Beshbeeshy, 1991

S. fuegonensis El Beshbeeshy, 1991

S. gayi gayi (Lamouroux, 1821)

S. grandensis El Beshbeeshy, 1991

S. hermanosensis El Beshbeeshy, 1991

S. jorgensis El Beshbeeshy, 1991

S. mogotensis El Beshbeeshy, 1991

S. paessleri Hartlaub, 1900

S. patagonica (D’Orbigny, 1839)

S. peregrina Bale 1926

S. picta (Meyen, 1834)

S. polyzonias Linnaeus, 1758

S. protecta Hartlaub, 1900

S. quadrifida Hartlaub, 1900

S. robusta Coughtrey, 1876

S. sanmatiasensis EI Beshbeeshy, 1991

S. stepanyantsae El Beshbeeshy, 1991

S. unilateralis (Lamouroux, 1824)

$S$ vervoorti El Beshbeeshy, 1991

Staurotheca Allman, 1888

S. jaederholmi (Stechow, 1920)

$S$ vervoorti (El Beshbeeshy 1991)

Symplectoscyphus Marktanner-Turneretscher, 1890

S. affinis (Hartlaub, 1900)

S. aggregatus (Jäderholm, 1917)

S. bathyalis Vervoort, 1972

S. chubuticus El Beshbeeshy, 1991

S. filiformis (Allman, 1888)

S. flexilis (Hartlaub, 1900)

S. leloupi El Beshbeeshy, 1991

S. magellanicus (Marktanner-Turneretscher, 1890)

S. margaritacea (Allman, 1885)

S. marionensis Millard, 1971

S. milneanus (D'Orbigny, 1846)

S. milneanus (Hartlaub, 1900)

S. modestus (Hartacialis El Beshbeeshy, 1991

S. pinnatus (Clark, 1876)

S. pulchella (Jäderholm, 1905)

S. salvadorensis El Beshbeeshy, 199

S. singularis El Beshbeeshy, 1991

S. subdichotomous (Kirchenpauer, 1884)

S. valdesicus El Beshbeeshy, 1991

$S$ vervoort $\mathrm{El}$ Beshbeeshy, 1991

Thuiaria Fleming, 1828

T. thuia (Linnaeus, 1758)

Syntheciidae Marktanner-Turneretscher, 1890

Synthecium Allman, 1872

S. robustum Nutting, 1900

Campanulariidae Hincks, 1868

Billardia Totton, 1930

B. subrufa (Jäderholm, 1904)

Campanularia Lamarck, 1816

C. agas Cornelius, 1982

C. hicksoni Totton, 1930

C. hincksii Alder, 1856

C. hincksil Alder, 1856

C. laevis Hartlaub, 1905

C. tincta Hincks, 186

C. hemisphaerica Linnaeus, 1767

C. noliformis (McCrady, 1857)

C. paulensis (Vanhöffen, 1910)

Gonothyraea Allman, 1864

G. loveni (Allman, 1859)

Hartlaubella Poche, 1914

H. gelatinosa Pallas, 1766

Laomedea Lamouroux, 1812

L. tottoni (Leloup, 1935)

Obelia Peron and Lesueur, 1810

O. bidentata Clarke, 1875

O. dichotoma (Linnaeus, 1758)

O. geniculata (Linnaeus, 1758 )

O. Oongissima (Pallas, 1766)

Orthopyxis Agassiz, 1862

O. clytoides (Lamouroux, 1824)

O. crenata (Hartlaub, 1900)

O. eurycalyx El Beshbeeshy, 1991

O. hartlaubi El Beshbeeshy, 1991

Silicularia Meyen, 1834

S. rosea Meyen, 1834

Tulpa Stechow, 1921

T. tulipifera (Allman, 1888)
CG

MA

CG

T/ST

CG

WG

BP

WT

$\mathrm{M}$
$\mathrm{M}$

MA

KP
A. mawsoni (Briggs, 1938)

A. spiralis (Hickson and Gravely, 1907)

ertularella Gray, 1847

Sertularella $\mathrm{sp} .1$

Sertularella sp. 2
Staurotheca Allman, 1888

S. affinis (Jäderholm, 1904)

S. amphorophora Naumov and Stepan'yants, 1962

S. antarctica Hartlaub, 1904

S. australis Peña Cantero et al., 1997

S. compressa Briggs, 1938

S. frigida Peña Cantero et al., 1997

S. glomulosa Peña Cantero et al., 1997

S. juncea (Vanhöffen, 1910)

S. nonscripta Peña Cantero et al., 1997

S. pachyclada (Jäderholm, 1904)

S. plana Peña Cantero et al., 1997

S. polarsterni Peña Cantero et al., 1997

S. stolonifera (Hartlaub, 1904)

S. undosiparietina (Stepan'yants, 1979)

S. vanhoeffeni (Peña Cantero and García Carrascosa, 1993)

Staurotheca sp. nov. 1

Staurotheca $\mathrm{sp}$. nov. 1

Staurotheca sp. nov.

Staurotheca sp. nor

Staurotheca sp. nov. 4

Staurotheca sp. nov. 5

Symplectoscyphus Marktanner-Turneretscher, 1890

S. aggregatus (Jäderholm, 1917)

S. cumberlandicus (Jäderholm, 1905)

S. curvatus (Jäderholm, 1917)

$S$. densestriatus Zhican, 1991

S. exochus Blanco, 1982

$S$. glacialis (Jäderholm, 1904)

S. hero Blanco, 1977

S. liouvillei (Billard, 1914)

S. liouvillei (Billard, 1914)

S. naumovi Blanco, 1969
S. nesioticus Blanco, 1977

S. nesioticus Blanco, 1977 plectilis (Hinckson and Gravley, 1907)

S. vanhoeffeni Totton, 1930

S. subdichotomous (Kirchenpauer, 1884)

Campanulariidae Hincks, 1868

Billardia Totton, 1930

B. intermedia Blanco, 1967

B. subrufa (Jäderholm, 1904)

Campanularia Lamarck, 1816

C. hicksoni Totton, 1930

C. hicksoni Totton, 1930

C. tincta Hincks, 1861

Obelia Peron and Lesueur, 1810

O. longissima (Pallas, 1766)

O. bidentata Clarke, 1875

Silicularia Meyen, 1834

S. rosea Meyen, 1834
EA

WA

WA

WA

WA
CA
AK

AK

WA

CA

WA

WA

WA

WA

CA

WA

WA

WA

AP

CA

WA

WA

AK

CA

WA

CA

CA

WA

AP

MA

BP 
At family level, as shown in Table 2, Sertulariidae is clearly the dominant family. This agrees with the results obtained by Stepan'yants (1979). Of 106 species of thecate hydroids recorded in the Antarctic region, 44 species ( $\mathrm{ca} 42 \%$ ) belong to that family. Kirchenpaueriidae is also an important family in the Antarctic benthic ecosystem, with records of 21 species (ca 20\%), all belonging to Oswaldella. The families Lafoeidae, Haleciidae and Halopterididae with nine species ( $\mathrm{ca} 8 \%$ ) and Campanulariidae with eight species $(\mathrm{ca} 8 \%)$ are also well represented, whereas the remaining families (Campanulinidae, Tiarannidae and Phialellidae) have little representation (three, two and one species, respectively).

The predominant life cycle (characterized by the suppression of the free-swimming stage) in the Antarctic thecate hydroid fauna might have favoured the high degree of endemism at specific level. In the Antarctic region primary production is highly seasonal and at most coastal sites is generally limited to the period of open water. However, a small fraction of nano- and picoplankton is available throughout the year (Froneman and Perissinoto, 1996). During the rest of the year redistribution of accumulated energy from one trophic level to another takes place (Picken, 1985). This fact might have favoured those groups of hydroids that have a reduced or even suppressed free-swimming stage. Thus, the majority of the known Antarctic thecate hydroid fauna has fixed gonophores and only a few species have medusae. In spite of the a priori lower dispersal potential of the fixed gonophores, there is a high number of CircumAntarctic species which may have been favoured by the uniform general conditions present throughout the Antarctic Ocean during a long time. The high number of endemic species in West Antarctica might merely reflect which part of Antarctica has been better studied and certainly future scientific surveys will change the distribution of many of those species to Circum-Antarctic.

\section{Antarctic hydroid fauna vs Magellan hydroid fauna}

As shown in Table 2, the Magellan area is richer than the Antarctic region concerning the biodiversity of thecate hydroids. At family level, it is remarkable that whereas the nine families of thecate hydroids with members in the Antarctic region also have representatives in the Magellan area, there are three families of thecate hydroids (Syntheciidae, Plumulariidae and Aglaopheniidae) with members in the Magellan area, but without representatives in the Antarctic region; the members of these three families are typically distributed in temperate and warm waters.

In the Magellan area, as in the Antarctic region, Sertulariidae is the dominant family. Thus, of 126 species ( $c f$. Table 2), 57 species $(45 \%)$ belong to this family. However, whereas in the Antarctic region the following family is Kirchenpaueriidae with $c a$ a $20 \%$ of the species (see above), in the Magellan area it is the family Campanulariidae with 22 species ( $c$ 17\%), followed by Lafoeidae with 13 species ( $\mathrm{ca} 10 \%)$.

The differences at generic level between both areas are greater than at family level. The two regions differ in the number of genera, in the presence/absence of certain genera and in the number of species of genera common to both.

The much higher diversity at generic level in the Magellan area is remarkable. Thus, as shown in Table 2, in the Magellan area species of 40 genera of thecate hydroids have been reported, whereas in the Antarctic region species of only 23 genera are known, representing $\mathrm{ca} 58 \%$. Consequently, there is a high number of Magellan genera without representatives in the Antarctic region. In contrast, with the exception of four genera (Lafoeina, Stegella, Halisiphonia and Antarctoscyphus), the remaining genera present in the Antarctic region also have representatives in the Magellan area. Stegella and Antarctoscyphus are genera that probably originated in the Antarctic region, being composed of either species endemic in that region or Pan-Antarctic species. Thus, as stated above, the single member of the genus Stegella has an Antarctic-Kerguelen distribution and of eight known species of Antarctoscyphus, seven are endemic in the Antarctic region, whereas the remaining one has an Antarctic-Kerguelen distribution.

There are two common genera that probably originated in the Antarctic region and that differ greatly in the number of species present both in the Antarctic region and in the Magellan area. Thus, as was stated above, of 23 species referred to Staurotheca, 19 species are endemic in the Antarctic region, two have an Antarctic-Kerguelen distribution and the remaining two are endemic in the Magellan area. Of 22 species referred to Oswaldella, 21 are endemic in the Antarctic region, the remaining one being endemic in the Magellan area. There are also large differences concerning the genus Schizotricha. Thus, of nine species recorded from 
Antarctic and Sub-Antarctic waters ( $c f$. Peña Cantero, 1998), a single species is present in the Magellan area, the remaining species being endemic in the Antarctic region.

On the other hand, there are genera in which the proportion is clearly contrary, having a larger number of species in the Magellan area. Thus, El Beshbeeshy (1991), in the Magellan area, referred 26 species to the genus Sertularella and 21 to the genus Symplectoscyphus, whereas in the Antarctic region two and 13 species, respectively, have been recorded.

The genus Abietinella, with its only known member (A. operculata), is shared both by the Antarctic region and the Magellan area, and might be considered to have an Antarctic-Patagonian distribution.

At specific level, though the diversity is higher in the Magellan area, the degree of endemism is lower in that area. As was stated above, of 104 species determined to specific level, 72 (69\%) are endemic in the Antarctic region. In the Magellan area, however, of 126 species, 49 (39\%) may be considered endemic.

The comparison between the thecate hydroid fauna known from both the Antarctic region and the Magellan area (Table 2) shows that only 23 species are present in both areas, representing $22 \%$ of the 104 species reported in the Antarctic region and $18 \%$ of the 126 species recorded in the Magellan area. These are species with a worldwide distribution (Halecium tenellum, H. delicatulum, Lafoea dumosa, Filellum serpens and Obelia bidentata), bipolar species (Stegopoma plicatile and Obelia longissima), species widely distributed in the southern hemisphere (Stegopoma irregularis, Filellum antarcticum, Symplectoscyphus subdichotomous and Campanularia tincta), species mainly SubAntarctic (Schizotricha multifurcata, Silicularia rosea), Pan-Antarctic species (Opercularella belgicae, Phialella chilensis, Hebella striata, Halecium jaederholmi, Hydrodendron arboreum) and, finally, species with an Antarctic-Patagonian distribution (Abietinella operculata, Hebella plana, Symplectoscyphus aggregatus and Billardia subrufa).

At present, it is difficult to know which species inhabiting the Antarctic region are of Magellan origin and migrated to Antarctica via the Scotia Ridge and, inversely, which species of Antarctic origin followed the opposite way. Before determining the relative importance of the contingent of species the Antarctic region and the Magellan areas have in common, it would be necessary to improve scientific knowledge concerning the hydroid fauna of both areas, since they are still poorly known, existing for instance vast Antarctic areas in which the hydroid fauna is completely unknown. It would also be necessary to know the relationships between the Antarctic hydroid fauna and that of other areas, mainly that of the Sub-Antarctic islands, but also that of New Zealand, South Australia and South Africa.

\section{ACKNOWLEDGEMENTS}

The authors wish to express their sincere gratitude to the Instituto Español de Oceanografía, especially to Ana Ramos, for the opportunity to study the material collected during the "Antártida 8611" expedition.

\section{REFERENCES}

Andriashev, A.P. - 1964. Obzor fauny ryb Antarktiki (Survey of the Antarctic Fish Fauna). Issled. Fauny Morei, 2 (10): 335-386 (in Russian).

Blanco, O. - 1994. Enumeración sistemática y distribución geográfica preliminar de los Hydroida de la República Argentina. Suborden Athecata (Gymnoblastea, Anthomedusae), Thecata (Calyptoblastea, Leptomedusae) y Limnomedusae. Rev. Mus. La Plata, n. ser., 14 (161): 181-216.

Brandt, A. - 1991. Zur Besiedlungsgeschichte des antarktischen Schelfes am Beispiel der Isopoda (Crustacea, Malacostraca). Ber. Polarforsch., 98: 1-240.

Briggs, J.C. - 1974. Marine Zoogeography. McGraw-Hill, Inc., New York.

El Beshbeeshy, M. - 1991. Systematische, morphologische und zoogeographische Untersuchungen an den thekaten Hydroiden des Patagonischen Schelfs. Ph.D. thesis, Univ. Hamburg.

Fronemann, P. and R. Perissinoto. - 1996. Microzooplankton grazing in the Southern Ocean: implications for the carbon cycle. Mar. Ecol., P.S.Z.N., 17 (1-3): 99-115.

Fry, W. G. - 1964. The pycnogonid fauna of the Antarctic continental shelf. In: R. Carrick, M. W. Holgate and J. Prevost (eds): Biologie Antarctique, pp. 263-269. Hermann, Paris.

Hartlaub, C. - 1905. Die Hydroiden der magalhaenischen Region und chilenischen Küste. Fauna Chilensis 3, Zool. Jb. (Suppl.), 6 (3): 497-714.

Hayward, P.J. - 1995. Antarctic Cheilostomatous Bryozoa. Oxford Univesity Press, Oxford.

Hedgpeth, J.W. - 1969. Introduction to Antarctic zoogeography. Antarct. Map Folio Ser., 11: 1-9.

Jazdzewski, K., W. Teodorczyk, J. Sicinski and B. Kontek. - 1991. Amphipod crustaceans as an important component of zoobenthos of the shallow Antarctic sublittoral. Hydrobiol., 223: 105117.

Knox, G.A. - 1995. The Biology of the Southern Ocean. Cambridge University Press, Cambridge.

Knox, G.A. and J.K. Lowry. - 1977. A comparison between the benthos of the Southern Ocean and the north polar ocean with special reference to the Amphipoda and the Polychaeta. In: M.J. Dunbar (ed.): Polar Oceans. Proceedings of the Polar Oceans Conference (Montreal, May 1974), pp. 423-462. Arctic Institute of North America, Calgary.

Pawson, D.L. - 1969. Echinoidea. Antarct. Map Folio Ser., 11: 38-41.

Peña Cantero, A.L. - 1998. Two new Antarctic species of the genus Schizotricha Allman, 1883 (Cnidaria, Hydrozoa). Polar Biol., 19: 77-84.

Peña Cantero, A.L. and A.M. García Carrascosa. - 1995. Hidrozoos bentónicos de la campaña Antártida 8611. Publ. Esp. Inst. Esp. Oceanogr., 19: 1-148. 
Peña Cantero, A.L. and A.M. García Carrascosa. - 1998. On Oswaldella vervoorti spec. nov. (Cnidaria, Hydrozoa), a new benthic hydroid from the South Shetland Islands (Antarctica). Zool. Verh., Leiden, 323: 175-180.

Peña Cantero, A.L., A.M. García Carrascosa and W. Vervoort. 1997. On Antarctoscyphus (Cnidaria, Hydrozoa), a new genus of antarctic hydroids and the description of two new species. Polar Biol., 18: 23-32.

Peña Cantero, A.L., A. Svoboda and W. Vervoort. - 1997a. Species of Staurotheca Allman, 1888 (Cnidaria, Hydrozoa) from recent antarctic expeditions with R.V. Polarstern, with the description of six new species. J. Nat. Hist., 31: 329-381.
Peña Cantero, A.L., A. Svoboda and W. Vervoort. - 1997b. Species of Oswaldella Stechow, 1919 (Cnidaria, Hydrozoa) from recent antarctic expeditions with R.V. 'Polarstern', with the description of eight new species. Zool. J. Linn. Soc., London, 119 (3): 339-388.

Peña Cantero, A.L. and W. Vervoort - 1998. On two new species of Oswaldella Stechow, 1919 (Cnidaria, Hydrozoa) from Bransfield Strait (Antarctica). Polar Biol., 20: 33-40.

Picken, G.B. - 1985. Marine habitats - benthos. In: W.N. Bonner and D.W.H. Walton (eds): Key Environments: Antarctica, pp. 154-172. Pergamon Press Ltd., Oxford.

Stepan'yants, S.D. - 1979. Hydroids of the Antarctic and Subantarctic waters. Issled. Fauny Morei, 20(30): 1-200 (in Russian). 